Arch. Tierz., Dummerstorf 50 (2007) 3, 227-239

Department of Animal Breeding and Genetics, University of Agriculture Faisalabad, Pakistan

\author{
M. SAJJAD KHAN, FAIZ UL HASSAN, M. SAIF UR REHMAN, ASAD ULLAH HYDER
} and IMRAN RAFIQUE BAJWA

\title{
Genetic control of milk yield from lactations of different duration in Nili-Ravi buffaloes
}

\begin{abstract}
Data on 2704 lactations of 1093 Nili-Ravi buffaloes were used to see the genetic control of milk yield projected for lactation length using information on last recorded yield and average daily yield of the recorded lactation. Year and season of calving and their interaction significantly affected actual and predicted milk yield. Winter calvers had a higher mean $(1364.5 \pm 31.63 \mathrm{~kg})$ as compared to summer calvers $(1299.4 \pm 30.28 \mathrm{~kg})$. The milk yield adjusted to 308-days increased from first parity $(1731.8 \pm 78.86 \mathrm{~kg})$ to third parity $(1919.6 \pm 64.56 \mathrm{~kg})$ where after it declined gradually. Age at calving with in parity affected lactation milk yield significantly $(\mathrm{P}<.01)$. Lactation length had a significant effect on actual and adjusted lactation yields but the effect was much smaller in projected lactations. Repeatability of actual lactation milk yield was $0.46 \pm 0.02$. Heritability of actual lactation milk yield from paternal half-sib correlation method was $0.244 \pm 0.057$. Lactations adjusted to 308 days by simple linear regression had a similar heritability $(0.243 \pm 0.057)$ but lactations adjusted using last record-day information had slightly better heritability estimate $(0.295 \pm 0.063$ to $0.314 \pm 0.065)$. Estimate improved as data set was restricted to include more completed. Results from Animal Model analysis indicated that overall heritability value for actual lactation milk yield was 9.1\% while for 308-day lactation milk yield (adjusted by using last record-day and or average daily milk yield information), value was 10.7 to $12.0 \%$. Extension of all lactation records with less than 305-days length to standard such as 305-days using last record-day and average daily milk yield information is suggested.
\end{abstract}

Key Words: Nili-Ravi, buffalo, milk yield, heritability, lactation length

\section{Zusammenfassung}

Titel der Arbeit: Genetische Kontrolle der Milchleistung bei unterschiedlicher Laktationslänge untersucht an Nili-Ravi Büffeln

Die Daten der 2704 Laktationen von 1093 Nili-Rahi Büffelkühen wurden für eine genetische Kontrolle des Milchertrages bei unterschiedlicher Laktationslänge unter Verwendung der Gesamtlaktationsleistung, der letzten erfassten sowie der durchschnittlichen täglichen Milchleistung genutzt. Jahr und Saison der Kalbung und ihre Interaktion beeinflussten signifikant den tatsächlichen und zu erwartenden Milchertrag. Dieser lag bei Winterim Vergleich zur Sommerkalbung höher (Wi. 1364,5 $\pm 31,6$ kg; So 1299,4 $\pm 30,3$ kg). Der Milchertrag bei 308 Laktationstagen stieg von der ersten $(1731,8 \pm 7887 \mathrm{~kg})$ zur dritten Laktation $(1919,6 \pm 64,6 \mathrm{~kg})$ an, um dann allmählich abzunehmen. Das Alter bei der Kalbung innerhalb der einzelnen Laktationen beeinflusste den Milchertrag signifikant $(\mathrm{P}<0,01)$. Auch die Laktationslänge hatte einen signifikanten Einfluss auf den tatsächlichen und den zu erwartenden Milchertrag. Dieser Einfluss verringerte sich jedoch mit steigender Laktationszahl. Die Wiederholbarkeitsschätzung des aktuellen Milchertrages ergab bei kürzester Laktationslänge den geringsten Wert von 0,46 $\pm 0,02$ und der Heritabilitätskoeffizient zu diesem Zeitpunkt,

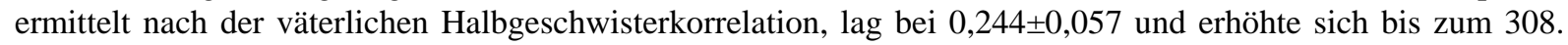
Laktationstag. Der Heritabilitätskoeffizient für die Laktationsleistung bezogen auf 308 Laktationstage ergab mittels einfacher linearer Regression einen geringeren Wert von 0,243 $\pm 0,057$ bezogen auf die kürzeste Laktationslänge, aber bezogen auf das letzte Prüfergebnis wurden vergleichsweise leicht verbesserte Schätzwerte von 0,295 $\pm 0,063$ bzw. 0,314 $\pm 0,065$ ermittelt, Die Ergebnisse der Analyse mittels Tiermodell zeigten, dass die gesamten Schätzwerte des tatsächlichen Milchertrages bei 9,1 \% lagen, während diejenigen für die 308 Laktationstage, verglichen mit dem letzten Kontrollergebnis oder dem durchschnittlichen täglichen Milchertrag 10,7 bis $12,0 \%$ betrugen. 
1. Introduction

Inclusion of incomplete lactations along with completed lactations helps reduce the bias in ranking of bulls for breeding values. Early estimates of sires' breeding values by extending incomplete lactations can also help to reduce the generation interval. The projected records can also be used to estimate cows' producing abilities while their lactations are still in progress and facilitate the farmers for early culling decisions. Duration of lactation length is the main criteria to declare any record complete or incomplete as information on reasons of drying is usually not available.

One option to resolve the issue of extending records is to use completed records which means loosing more than $50 \%$ of the data if standard lactation is of 10 months which is not judicious utilization of resources and cause bias in ranking in breeding values for milk yield. The other option is to consider lactations of shorter duration as the ability of the buffalo and not project such lactations declaring them as completed lactations. Previously such suggestions have been made both for cows (VAN VLECK and HENDERSON, 1961) and buffaloes (KHAN, 1986). The problem with such a decision is that which lactation should be declared shorter i.e., a lactation of 60 days or a lactation of 285 days. Different cut offs are available in the literature ranging from 28 to 285 days and the issue has previously been discussed (KHAN, 1996). Another solution is to project all records, complete or incomplete. This is being followed in US production system. NORMAN et al. (1985) has suggested this strategy for Holsteins due to better genetic parameters of projected records and also because credit given to a cow of completed lactations is very little when projection is based on last record-day yield as prediction is made only for unknown part of the lactation.

For buffaloes, procedures to project incomplete lactations using last record-day information have been developed but credit given to a buffalo for unknown lactation period depended only on the lactation length and last recorded milk yield. The procedure was more accurate than the other methods of projection yet, it did not differentiate between high and low producing buffaloes with similar last recorded milk yield. KHAN et al. (2005) presented an improvement of the last record-day procedure by including the average milk yield of the recorded lactation period. The method had a lesser bias, improved accuracy and credit given to a lactation of certain duration was more reasonable than if last record-day information was used as the only predictor. The impact of this improved prediction method on genetic control of projected milk yield is presented in the present study.

2.

Materials and Methods

Milk yield records of 993 Nili-Ravi buffaloes, maintained at Livestock Experiment Station, Bahadurnagar, Okara were used for the present study. A total of 2704 lactations were available with lactation length of at least 60 days. If milk yield was missing for any week, it was estimated by averaging previous and next available weekly record. However, if milk yield information was missing for more than 56 days consecutively, such records were excluded. Errors in data entry were minimized by deleting outliers and allowing a maximum of $100 \%$ increase/decrease between two consecutive weeks. Season of calving was defined as summer (for buffaloes calving from April to September) and Winter (for buffaloes calving from October to March). 
Adjustment procedures

Five types of adjustments for adjusting shorter lactations to 308-day yield were considered.

1. Milk yield adjusted by using a simple regression equation proposed by KHAN (1986). The adjusted milk yield using this simple linear regression was named as MYSRF.

2. Milk yield adjusted by using factors calculated on the basis of last record-day procedures (KHAN and IQBAL, 1996). All lactations of $\geq 308$ day duration were used for the calculation of equations to predict future milk yield and the adjusted lactation milk yield was called MYATYP. In this adjustment procedure 308-day milk yield was estimated using last record-day yield information (milk yield of morning and evening milkings added together on the last record). The 308-day milk yield was estimated as follows:

$\hat{\mathrm{Y}}_{308}=\mathrm{Y}_{\mathrm{t}}+\hat{\mathrm{Y}}_{\mathrm{f}}(308-\mathrm{DIM})$

Where $\hat{Y}_{308}$ is extended 308-day milk yield for lactation of any length; $Y_{t}$ is total milk yield produced before the termination of lactation or milk yield of recorded lactation, DIM is days in milk and $\hat{Y}_{\mathrm{f}}$ is Predicted daily milk yield for unknown part of lactation was estimated as follows:

$\hat{\mathrm{Y}}_{\mathrm{f}}=\mathrm{a}+\mathrm{b} \mathrm{X}_{\mathrm{i}}$

Where, $\hat{Y}_{\mathrm{f}}$ is predicted future daily yield at any lactation length, $\mathrm{a}$ is the intercept, $\mathrm{b}$ is the regression coefficient, $\mathrm{X}_{\mathrm{i}}$ is the available milk yield on the last record-day at any lactation length

3. Milk yield adjusted by using factors calculated on the basis of last record-day procedure, similar to 2) above but excluding lactations that were atypical.

To determine whether a lactation is typical or atypical, a gamma-type function Wood (1967) was used as follows:

$\mathrm{Y}=\mathrm{a} \mathrm{b}^{\mathrm{n}} \mathrm{e}^{-\mathrm{cn}}$

Where, $\mathrm{Y}$ is daily milk yield $(\mathrm{kg})$, recorded at a weekly interval, $\mathrm{n}$ is week of lactation length (1 to 44) and a,b,c represent coefficients representing intercept, rate of increase towards peak and rate of decline from the peak.

The logarithmic form of the model given below was applied to individual lactations. $\ln (\mathrm{Y})=\ln (\mathrm{a})+\mathrm{b} \ln (\mathrm{n})-\mathrm{c} \mathrm{n}$

Lactations were considered atypical if $b$ in the above model was negative (i.e., $a$ decline in milk yield after calving, instead of an increase) or if c in the above model was positive (i.e., an increase after the peak instead of a decline). There were 253 such lactations leaving 2451 lactations to be used for the development of regression equations. The factors developed were used to estimate 308-day milk yield and the estimated lactation milk yield variable was named as MYTP1.

4. To utilize short lactations (< 308 days) a ratio of the milk yield to be estimated and last record-day yield was obtained [ratio $=$ (308-day milk yield - milk yield for recorded lactation) / last record-day milk yield] from the 308-day complete lactations and 308-day yield was estimated for the short lactations. This made it possible to estimate future daily yield and the regression equations could be developed from all the data set to predict future daily yield and then the 308-day yield. The predicted 308day yields were called MYTP2. 
5. To account for variation in the behavior of lactation curves for low and high producing animals with a similar last record-day yield, regression equation to predict future daily milk yield was modified. Future daily yield for the short lactations was not only predicted from the last record-day yield available (KHAN and IQBAL, 1996; AKRAM, 1997) but average daily yield of the known part of the lactation was also utilized. The regression equation was as follows:

$\hat{Y}_{\mathrm{f}}=\mathrm{a}+\mathrm{b}_{1} \mathrm{X}_{1}+\mathrm{b}_{2} \mathrm{X}_{2}$

Where $\hat{Y}_{\mathrm{f}}$ is predicted future daily yield at a certain lactation length, a is the intercept, $b_{1}$ and $b_{2}$ are regression coefficients and $X_{1}$ is available milk yield on the last recordday at a certain lactation length and $X_{2}$ average daily milk yield of known part of the lactation at a certain lactation length. The 308-day milk yield was then predicted as described above and the predicted 308-day milk yield was named as MYTP3.

Heritability estimation

Heritability of un-extended (MYTOT) and extended milk yield (MYSRF, MYTP1, MYTP2, MYTP3) was estimated by paternal half-sib correlation assuming the following model.

$\mathrm{Y}_{\mathrm{ijkl}}=\mu+$ Sire $_{\mathrm{i}}+\mathrm{YS}_{\mathrm{j}}+\mathrm{Age}_{\mathrm{k}}+\mathrm{e}_{\mathrm{ijkl}}$

Where

$\mathrm{Y}_{\mathrm{ijkl}} \quad$ Milk yield up to 308-days of lactation (extended or un-extended)

$\mu \quad$ Population mean

Sire $_{i} \quad$ Random sire effect

$\mathrm{YS}_{\mathrm{j}} \quad$ Fixed effect of year and season combination of calving (1 to 54)

Age $_{k}$ Fixed effect of age defined within parity, 35 age classes defined within parity (KHAN and IQBAL, 1996)

$\mathrm{e}_{\mathrm{ijkl}} \quad$ Random error

The ratio of sire variance to total variance from the above model was multiplied by 4 for heritability estimation. For the individual lactations, model was similar to the above except that age classes were limited for that particular parity. Data sets used for the estimation of heritability and repeatability of lactation milk yield by including records of various lactation lengths were the same except that cows were the random source of variation in the repeatability model and adjacent years were pooled into periods, called year groups.

Additive and permanent environmental variances were also calculated fitting an individual Animal Model for the four variables of 308-day milk yield and lactation length. The model was as follows:

$\mathrm{Y}_{\mathrm{ijk}}=\mathrm{YS}_{\mathrm{i}}+$ Anim $_{\mathrm{j}}+$ Perm $_{\mathrm{j}}+\mathrm{b}_{1}$ Age $+\mathrm{b}_{2}$ Age $^{2}+\mathrm{e}_{\mathrm{ijk}}$

Where

$\mathrm{YS}_{\mathrm{i}} \quad$ Combined effect of year and season of calving

Anim $_{\mathrm{j}} \quad$ Random animal genetic effect

Perm $_{j} \quad$ Random permanent environmental effect

$b_{1}$ and $b_{2} \quad$ Regression coefficients

Age Age at calving (in months)

$\mathrm{e}_{\mathrm{ijk}} \quad$ Random temporary environment effect (residual effect). 
For linear models and regression analysis SAS ${ }^{\circledR}$ (1990) was used while for heritability and repeatability estimation, LSMLMW (HARVEY, 1990) was used. Calculation of additive genetic and permanent environmental variance through Animal Model was accomplished by Derivative Free Restricted Maximum Likelihood (DFREML) software (MEYER, 1997).

\section{3.}

\section{Results and discussion}

Basic statistics

Frequency distribution of lactations according to lactation length (or days in milk) indicated that out of 2704 lactations having more than 56 days of duration, $59.2 \%$ had shorter lactation than 308 days of duration (Table 1). If minimum was increased from 56 to 112 days, this included $3.0 \%$ of all the lactations. Buffaloes with lactations of more than 182 days duration were $89.2 \%$ of the data set. It may be mentioned that lactations with lactation length (LL) of less than 56 days were not included in the data set and the values do not represent population averages. Such lactations were less than $5 \%$ of the total lactations included the study period. Expected shorter lactations had lower milk yield as compared to the complete or longer lactations. Milk yield averaged $1984.4 \mathrm{~kg}$ with a standard deviation of $773.43 \mathrm{~kg}$ when information up to 308 days was used. Lactation length for these records averaged 266.6 days with a standard deviation of 55.15 days. Actual average lactation length of these records was 289.6 \pm 82.12 days. Very short lactations (56-77 days in milk) had average milk yield of $347.1 \mathrm{~kg}$ with a standard deviation of $148.53 \mathrm{~kg}$.

Table 1

Frequency distribution of lactations by lactation length and averages $( \pm \mathrm{SD})$ of milk yield and lactation length (Beschreibung der unterschiedlichen Laktationslänge und des jeweiligen Milchertrages)

\begin{tabular}{crrcr}
\hline Lactation length (days) & $\mathrm{N}$ & $\%$ & Lactation length & Milk yield \\
\hline $56-77$ & 30 & 1.1 & $75.0 \pm 12.00$ & $347.1 \pm 148.53$ \\
$84-105$ & 51 & 1.9 & $106.1 \pm 24.82$ & $549.1 \pm 186.50$ \\
$112-133$ & 56 & 2.1 & $133.0 \pm 25.40$ & $704.0 \pm 174.89$ \\
$140-161$ & 79 & 2.9 & $160.6 \pm 19.41$ & $858.0 \pm 287.64$ \\
$168-189$ & 98 & 3.6 & $184.6 \pm 14.21$ & $1066.3 \pm 308.29$ \\
$196-217$ & 207 & 7.6 & $213.0 \pm 11.12$ & $1326.7 \pm 355.36$ \\
$224-245$ & 270 & 10.0 & $239.5 \pm 14.39$ & $1694.6 \pm 471.03$ \\
$252-273$ & 422 & 15.6 & $267.8 \pm 09.26$ & $1954.2 \pm 503.18$ \\
$280-301$ & 389 & 14.4 & $294.4 \pm 08.30$ & $2198.2 \pm 622.37$ \\
$\geq 308$ & 1102 & 40.8 & $307.0 \pm 08.07$ & $2453.5 \pm 618.78$ \\
\hline OVERALL & 2704 & 100.0 & $266.6 \pm 55.15$ & $1984.4 \pm 773.43$
\end{tabular}

\section{Actual vs Predicted milk yield}

Regression equations were developed for adjusting lactations to a standard lactation length of 308-days using the last record-day information. Predicted yields were calculated both from the regression equations when atypical lactations were in the data set (MYATYP) and when such lactations were excluded (MYTP1). Milk yield using the correction factors developed by KHAN (1986) and currently being used were also predicted (MYSRF). Actual lactation milk yield (MYTOT) and extended lactation milk yield (MYSRF, MYATYP, MYTP1, MYTP2 and MYTP3) along with standard deviations using different procedures of adjusting for 308-days yield are presented in Table 2. The actual lactation milk yield was $1984.4 \mathrm{~kg}$ for an average lactation length 
of 266.6 days (yield beyond 308-days excluded). The difference of actual and predicted gradually reduced with increase in lactation length. When extrapolation was made using last record-day information (i.e. predicting yield of unknown part of the lactation period only (MYATYP, MYTP1), predicted yield had lesser variation however, as compared to when a linear regression was used (651.99 to $655.62 \mathrm{~kg}$ standard deviation as compared to $772.52 \mathrm{~kg}$ ). Predicted milk yield was generally higher (except for 56-77 days of lactation length) when prediction equations included all the records (MYATYP) as compared to using typical lactations only (MYTP1). Difference between MYATYP and MYTP1 however, was small and reduced to almost zero for lactations with lactation length nearer to 308 days. The variable MYATYP was thus dropped from further analysis.

When shorter lactations were included in the development of prediction equations (MYTP2, MYTP3), predicted milk yield was lower as compared to predicted milk yield from equations using lactations with $\geq 308$ days of duration (MYTP1). This was especially true for shorter lactation length groups. Predicted milk yield for 56-77 days lactation length group was 1417.1, 1137.4 and $1099.1 \mathrm{~kg}$ for MYTP1, MYTP2 and MYTP3, respectively (Table 2). The difference among the three variables however, reduced for higher lactation length groups. The standard deviation of bias and correlation between actual and predicted lactation milk yield indicated that inclusion of average daily milk yield as a predictor along with the last record-day milk yield was a better choice when all lactation records were used (MYTP2 vs. MYTP3). It decreased standard deviation of bias and improved the correlation between actual and predicted milk yield. Lower values of bias and better correlation between actual and predicted milk yield for MYTP1 were due to the analysis of completed lactations only.

Table 2

Average \pm standard deviation of milk yield for different lactation length classes (Mittelwert und Standardabweichung der Milchleistung der unterschiedlichen Laktationslängengruppen)

\begin{tabular}{|c|c|c|c|c|c|c|}
\hline \multirow{2}{*}{$\begin{array}{c}\text { Lactation } \\
\text { length } \\
\text { (days) }\end{array}$} & \multirow[b]{2}{*}{ MYTOT $^{1}$} & \multicolumn{5}{|c|}{ Milk yield adjusted for lactation length } \\
\hline & & MYSRF $^{2}$ & MYATYP $^{3}$ & MYTP1 $^{4}$ & MYTP2 $^{5}$ & MYTP3 $^{6}$ \\
\hline $56-77$ & $347 \pm 148.5$ & $347 \pm 148.5$ & $1413 \pm 433.2$ & $1417 \pm 438.9$ & $1137 \pm 458.7$ & $1099 \pm 455.7$ \\
\hline 84-105 & $549 \pm 186.5$ & $549 \pm 186.5$ & $1458 \pm 437.4$ & $1436 \pm 442.8$ & $1197 \pm 462.8$ & $1190 \pm 444.8$ \\
\hline $112-133$ & $704 \pm 174.9$ & $704 \pm 174.9$ & $1407 \pm 275.4$ & $1377 \pm 280.7$ & $1171 \pm 291.0$ & $1178 \pm 292.6$ \\
\hline $140-161$ & $858 \pm 287.6$ & $858 \pm 287.6$ & $1407 \pm 378.1$ & $1371 \pm 384.9$ & $1226 \pm 394.0$ & $1225 \pm 408.8$ \\
\hline 168-189 & $1066 \pm 308.3$ & $1178 \pm 405.1$ & $1497 \pm 370.7$ & $1478 \pm 373.9$ & $1380 \pm 376.0$ & $1390 \pm 390.2$ \\
\hline $196-217$ & $1327 \pm 355.4$ & $1825 \pm 481.5$ & $1673 \pm 395.7$ & $1664 \pm 396.5$ & $1594 \pm 399.1$ & $1596 \pm 412.4$ \\
\hline $224-245$ & $1695 \pm 471.0$ & $2147 \pm 688.3$ & $1948 \pm 499.5$ & $1943 \pm 500.0$ & $1904 \pm 501.6$ & $1907 \pm 510.4$ \\
\hline $252-273$ & $1954 \pm 503.2$ & $2205 \pm 559.2$ & $2099 \pm 509.7$ & $2097 \pm 509.8$ & $2079 \pm 510.9$ & $2083 \pm 516.6$ \\
\hline $280-301$ & $2198 \pm 622.4$ & $2282 \pm 640.1$ & $2254 \pm 624.7$ & $2253 \pm 624.8$ & $2249 \pm 626.1$ & $2252 \pm 628.7$ \\
\hline$\geq 308$ & $2454 \pm 618.8$ & $2454 \pm 618.8$ & $2454 \pm 618.8$ & $2454 \pm 618.8$ & $2453 \pm 618.6$ & $2453 \pm 618.5$ \\
\hline Overall & $1984 \pm 773.4$ & $2123 \pm 772.5$ & $2140 \pm 652.0$ & $2138 \pm 655.6$ & $2105 \pm 522.1$ & $2107 \pm 688.1$ \\
\hline \multicolumn{7}{|c|}{$\begin{array}{l}\text { Actual milk yield; }{ }^{2} \text { Prediction equations had lactation length (>180 days) only (KHAN, 1986). } \\
\text { Prediction equations based on last record-day procedure; all lactations of } \geq 308 \text { days duration were used in calculations. } \\
{ }^{4} \text { Prediction equations based on last record-day procedure; only typical lactations of } \geq 308 \text { days duration were used in calculations. } \\
\text { Prediction equations based on last record-day procedure; only typical lactations of } \geq 56 \text { days duration were used in calculations. } \\
\text { Prediction equations based on last record-day procedure but having daily milk yield also; only typical lactations of } \geq 56 \text { days duration were } \\
\text { used in calculations. }\end{array}$} \\
\hline
\end{tabular}


Environmental factors and phenotypic trends

F-values from analysis of variance for various factors affecting lactation milk yield are presented in Table 3. Milk yield traits were significantly affected by variation due to cows. Actual lactation milk yield (MYTOT) and adjusted milk yield (MYSRF and MYTP1, MYTP2, MYTP3) were 44.2, 40.3, 43.0, 43.0 and 43.1 \% repeatable. Year of calving groups also significantly affected these yield traits as did the season of calving and interaction between the two.

Table 3

F-values from analysis of variance for various factors affecting lactation milk yield (F-Werte der Varianzanalyse für die Milchleistung beeinflussenden Varianzfaktoren)

\begin{tabular}{|c|c|c|c|c|c|c|}
\hline \multirow[b]{2}{*}{ Source } & \multirow[b]{2}{*}{ df } & \multirow[b]{2}{*}{ MYTOT $^{1}$} & \multicolumn{4}{|c|}{ Milk yield adjusted for lactation length } \\
\hline & & & MYSRF $^{2}$ & MYTP $^{3}$ & MYTP2 $^{4}$ & MYTP3 $^{5}$ \\
\hline Cow (random) & 992 & $3.08^{* *}$ & $2.77^{* *}$ & $2.98^{* *}$ & $2.98^{* *}$ & $2.99^{* *}$ \\
\hline Year group & 13 & $31.31^{* *}$ & $23.77^{* *}$ & $29.58^{* *}$ & $29.50^{* *}$ & $29.79^{* *}$ \\
\hline Season of calving & 1 & $9.92^{* *}$ & $7.24^{* *}$ & $8.39^{* *}$ & $9.62^{* *}$ & $10.74^{* *}$ \\
\hline Year group*Season & 13 & $2.70^{* *}$ & $2.59^{* *}$ & $2.91^{* *}$ & $2.99^{* *}$ & $3.02^{* *}$ \\
\hline $\begin{array}{l}\text { Days in milk (grouped } \\
\text { over weeks) }\end{array}$ & 36 & $50.16^{* *}$ & $35.81^{* *}$ & $13.80^{* *}$ & $19.62^{* *}$ & $19.52^{* *}$ \\
\hline Age within parity & 34 & $4.44^{* *}$ & $4.33^{* *}$ & $4.03^{* *}$ & $3.98^{* *}$ & $3.96^{* *}$ \\
\hline Error & 1614 & & & & & \\
\hline
\end{tabular}

${ }^{1}$ Actual milk yield; ${ }^{2}$ Prediction equations had lactation length ( $>180$ days) only (KHAN, 1986).

${ }^{3}$ Prediction equations based on last record-day procedure; only typical lactations of $\geq 308$ days duration were used in calculations.

${ }^{4}$ Prediction equations based on last record-day procedure; only typical lactations of $\geq 56$ days duration were used in calculations.

${ }^{5}$ Prediction equations based on last record-day procedure but having daily milk yield also; only typical lactations of $\geq 56$ days duration were used in calculations.

${ }^{* * *}$ Significant $(\mathrm{P}<.01)$

The overall mean $( \pm S E)$ for the three milk yield variables were 1332.0 \pm 29.19 , 1484.1 $\pm 31.10,1810.22 \pm 29.99,1692.0 \pm 30.06$ and $1690.4 \pm 30.20 \mathrm{~kg}$, respectively. Actual lactation milk yield and 308-day adjusted milk yield generally decreased across the years. Maximum values for MYTOT, MYSRF and MYTP1 were 1957.0 \pm 159.90 , 2041.5 \pm 180.25 , 2410.5 \pm 167.26 , 2297.3 \pm 165.89 and $2309.4 \pm 166.35 \mathrm{~kg}$, respectively for 1970-71, where after it decreased to the lowest values in 1980-81. Then there was a slightly increasing trend but values with an overall negative trend across the years. The lowest values for 1980-81 can be attributed to heavy rain falls, resulting in forage shortage in these years (DAHLIN, 1998). The overall mean is lower than the earlier reports (KHAN, 1996; KHAN and IQBAL, 1996) because of inclusion of shorter lactations in the present study. The adjusted milk was higher as compared to the actual milk yield because of adjustment to a higher base (308-days) as compared to the average (266 days) as mentioned earlier. Huge difference between the MYSRF and MYTP1 was because in MYSRF extrapolation of records for less than 180 days was not possible for shorter lactations and milk yield was assumed as the production potential of the animals (KHAN, 1986). Values for MYTP2 and MYTP3 were lower than MYTP1 because shorter lactations had been included in the development of regression equations.

Winter calvers had a significantly higher actual milk yield $(1364.5 \pm 31.63 \mathrm{~kg})$ as compared to summer calvers $(1299.4 \pm 30.28 \mathrm{~kg})$. Seasonal affects were however, not consistent across the years, resulting in a significant year by season interaction for all the lactation milk yield variables. Age within parity significantly $(\mathrm{P}<.01)$ affected milk yield. There was no clear trend for age groups within parities. For second parity buffaloes however, younger calvers had lower milk yield as compared to the older 
buffaloes but buffaloes calving at a very old age again had a lower estimate for actual (MYTOT) and adjusted milk yield (MYSRF, MYTP1, MYTP2 and MYTP3). It increased towards third parity (1438.2 \pm 61.93$)$ being maximum there and then followed a gradual decline. Trend was similar when milk yields had previously been adjusted for a lactation length (MYSRF, MYTP1, MYTP2 and MYTP3) and highest estimates were observed for MYTP1 as discussed previously.

Weeks in milk had a significant effect on lactation milk yield yet, as evident from the F-values (Table 3), the effect reduced to a greater extent when lactations had been adjusted for lactation length. For adjusted lactation milk yields, adjusted lactation yields from last record-day information (using complete lactations of 308-day duration) had lower F-values (13.80) as compared to the adjustments by simple linear regression procedure where F-value for this effect was 35.81. F-values for MYTP2 and MYTP3 were 19.62 and 19.52, respectively. As mentioned previously, there was over adjustment using simple linear regression procedure as compared to the adjustments from last record-day information. A dip in the milk yield at $11^{\text {th }}$ week of lactation was due to very few observations for shorter lactations and some influential observations. Among the last record-day adjustment procedures, MYTP1 had higher values as compared to MYTP2 and MYTP3.

Lactation milk yield is most commonly reported performance trait for buffaloes. Lactation milk yield has been quite variable among and even within breeds. Simple lactation averages do not tell much about this trait unless other traits controlling most of variation in it are reported. CADY et al. (1983) reported that adjusted milk yield (for environmental effects) was $1883 \pm 60 \mathrm{~kg}$ for a lactation length of 282 days in NiliRavi buffaloes. Milk yield adjusted to 305-days of length and age at calving to 60 months have been reported to be $2022 \pm 14.8 \mathrm{~kg}$. First parity buffaloes had an average of $1922 \pm 21.9 \mathrm{~kg}$ while average milk yield for later parity buffaloes was $2078 \pm 19.5 \mathrm{~kg}$ (KHAN, 1996). Average milk yield for Italian buffaloes have been reported to be 1963 $\mathrm{kg}$ with standard deviation of $614 \mathrm{~kg}$ and an average lactation duration of $268 \pm 67$ days (PILLA and MOIOLI, 1992).

\section{Genetic parameters}

Heritability estimates of milk yield using paternal half-sib correlation method are presented in Table 4. For 2235 observations having sire identification, and lactation length of $\geq 56$ days, heritability for actual milk yield (MYTOT) averaged $0.244 \pm 0.057$. For lactation records adjusted by linear regression procedure (MYSRF) heritability estimate was similar $(0.243 \pm 0.057)$. For lactation yields adjusted by using last record-day information (using completed lactations, MYTP1) however, heritability of milk yield was $0.314 \pm 0.065$. When shorter lactations were used in the development of regression equations (MYTP2 and MYTP3) heritability estimates were $0.299 \pm 0.063$ and $0.295 \pm 0.063$, respectively. When data set was restricted by lactation length i.e. more completed lactations, heritability generally increased indicating that environmental portion of the variance decreased. For the data set having $\geq 280$ days of lactation length, milk yield was $34-35 \%$ heritable. The actual 308 days lactation milk yield had a heritability of $26.2 \%$. For MYTP3, where lactation milk yield adjustments were more precise as compared to the MYTP1 and MYTP2, heritability estimates were slightly lower (but statistically similar) than MYTP1 for 
data sets having shorter lactations. Unadjusted milk yield (MYTOT) always had higher environmental and lower additive genetic variance.

Table 4

Heritability estimates of milk yield for different lactation length groups (Heritabilitätsschätzwerte der Milchleistung für die unterschiedlichen Laktationslängengruppen)

\begin{tabular}{ccccccc}
\hline \multirow{2}{*}{$\begin{array}{c}\text { Lactation } \\
\text { length }\end{array}$} & Obs. & MYTOT $^{1}$ & MYSRF $^{2}$ & MYTP1 $^{3}$ & MYTP2 $^{4}$ & MYTP3 $^{5}$ \\
\cline { 3 - 6 } (days) & & & & & & \\
\hline$\geq 56$ & 2235 & $0.244 \pm 0.057$ & $0.243 \pm 0.057$ & $0.314 \pm 0.065$ & $0.299 \pm 0.063$ & $0.295 \pm 0.063$ \\
$\geq 84$ & 2203 & $0.277 \pm 0.061$ & $0.276 \pm 0.061$ & $0.321 \pm 0.066$ & $0.310 \pm 0.065$ & $0.309 \pm 0.065$ \\
$\geq 112$ & 2159 & $0.276 \pm 0.061$ & $0.282 \pm 0.062$ & $0.323 \pm 0.066$ & $0.309 \pm 0.065$ & $0.309 \pm 0.065$ \\
$\geq 140$ & 2109 & $0.282 \pm 0.063$ & $0.297 \pm 0.064$ & $0.325 \pm 0.067$ & $0.312 \pm 0.066$ & $0.311 \pm 0.066$ \\
$\geq 168$ & 2046 & $0.286 \pm 0.064$ & $0.312 \pm 0.067$ & $0.325 \pm 0.068$ & $0.313 \pm 0.067$ & $0.313 \pm 0.067$ \\
$\geq 196$ & 1965 & $0.290 \pm 0.066$ & $0.321 \pm 0.069$ & $0.327 \pm 0.070$ & $0.315 \pm 0.068$ & $0.314 \pm 0.068$ \\
$\geq 224$ & 1807 & $0.316 \pm 0.071$ & $0.347 \pm 0.074$ & $0.351 \pm 0.075$ & $0.345 \pm 0.074$ & $0.345 \pm 0.074$ \\
$\geq 252$ & 1608 & $0.296 \pm 0.073$ & $0.338 \pm 0.078$ & $0.326 \pm 0.076$ & $0.325 \pm 0.076$ & $0.325 \pm 0.076$ \\
$\geq 280$ & 1286 & $0.336 \pm 0.087$ & $0.341 \pm 0.088$ & $0.342 \pm 0.088$ & $0.354 \pm 0.089$ & $0.354 \pm 0.089$ \\
$\geq 308$ & 964 & $0.262 \pm 0.096$ & $0.262 \pm 0.096$ & $0.262 \pm 0.096$ & $0.262 \pm 0.096$ & $0.262 \pm 0.096$ \\
\hline
\end{tabular}

${ }^{1}$ Actual milk yield; ${ }^{2}$ Prediction equations had lactation length ( $>180$ days) only (KHAN, 1986).

${ }^{3}$ Prediction equations based on last record-day procedure; only typical lactations of $\geq 308$ days duration were used in calculations.

${ }^{4}$ Prediction equations based on last record-day procedure; only typical lactations of $\geq 56$ days duration were used in calculations.

${ }^{5}$ Prediction equations based on last record-day procedure but having daily milk yield also; only typical lactations of $\geq 56$ days duration were used in calculations.

Although, observations for the analysis of individual parities were limited, heritability increased with increase in parity (Table 5). Milk yield adjusted by using last recordday milk yield (MYTP1) had higher values for most of the parities. Variance for some of the parities could not be estimated due to confounding.

Table 5

Heritability estimates of milk yield for different parities (Heritabilitätsschätzwerte der Milchleistung bei unterschiedlicher Laktationsnummer)

\begin{tabular}{|c|c|c|c|c|c|c|}
\hline \multirow[b]{2}{*}{ Parity } & \multirow[b]{2}{*}{ Obs. } & \multirow[b]{2}{*}{ MYTOT $^{1}$} & \multicolumn{4}{|c|}{ Milk yield adjusted for lactation length } \\
\hline & & & MYSRF $^{2}$ & MYTP1 $^{3}$ & MYTP2 $^{4}$ & MYTP3 $^{5}$ \\
\hline 1 & 595 & $0.054 \pm 0.121$ & - & $0.173 \pm 0.132$ & $0.124 \pm 0.127$ & $0.136 \pm 0.129$ \\
\hline 2 & 485 & $0.134 \pm 0.155$ & $0.231 \pm 0.162$ & $0.218 \pm 0.161$ & $0.155 \pm 0.157$ & $0.181 \pm 0.158$ \\
\hline 3 & 375 & $0.280 \pm 0.200$ & $0.226 \pm 0.196$ & $0.198 \pm 0.194$ & - & $0.225 \pm 0.198$ \\
\hline 4 & 280 & $0.662 \pm 0.279$ & $0.614 \pm 0.278$ & $0.836 \pm 0.285$ & - & $0.715 \pm 0.282$ \\
\hline$\geq 5$ & 503 & $0.204 \pm 0.133$ & $0.398 \pm 0.157$ & $0.441 \pm 0.161$ & $0.449 \pm 0.163$ & $0.470 \pm 0.165$ \\
\hline
\end{tabular}

${ }^{1}$ Actual milk yield; ${ }^{2}$ Prediction equations had lactation length (>180 days) only (KHAN, 1986).

${ }^{3}$ Prediction equations based on last record-day procedure; only typical lactations of $\geq 308$ days duration were used in calculations.

${ }^{4}$ Prediction equations based on last record-day procedure; only typical lactations of $\geq 56$ days duration were used in calculations.

${ }^{5}$ Prediction equations based on last record-day procedure but having daily milk yield also; only typical lactations of $\geq 56$ days duration were used in calculations.

Repeatability estimates had trend similar to the heritability estimates (Table 6). Actual lactation milk yield was less repeatable as compared to MYTP1. Extending records using last record-day procedures resulted in higher heritability and repeatability estimates as compared to actual milk yield (MYTOT) or milk yield extended by using simple regression procedure (MYSRF). Adjusted milk yield using last record-day information and information of average daily milk yield of the known part of the lactation curve (MYTP3) had repeatability of 49 to 54\% when data sets of different lactation duration were included. 
Repeatability estimates of milk yield for different lactation length groups (Wiederholbarkeitsschätzung für Milchertrag bei unterschiedlichen Laktationslängengruppen)

\begin{tabular}{|c|c|c|c|c|c|c|}
\hline \multirow[b]{2}{*}{$\begin{array}{c}\text { Lactation } \\
\text { length (days) }\end{array}$} & \multirow[b]{2}{*}{ Obs. } & \multirow[b]{2}{*}{ MYTOT $^{1}$} & \multicolumn{4}{|c|}{ Milk yield adjusted for lactation length } \\
\hline & & & MYSRF $^{2}$ & $\mathrm{MYTP}^{3}$ & MYTP2 $^{4}$ & MYTP3 $^{5}$ \\
\hline$\geq 56$ & 2235 & $0.463 \pm 0.022$ & $0.437 \pm 0.023$ & $0.493 \pm 0.022$ & $0.495 \pm 0.022$ & $0.494 \pm 0.022$ \\
\hline$\geq 84$ & 2203 & $0.471 \pm 0.022$ & $0.439 \pm 0.023$ & $0.492 \pm 0.022$ & $0.494 \pm 0.022$ & $0.492 \pm 0.022$ \\
\hline$\geq 112$ & 2159 & $0.484 \pm 0.022$ & $0.456 \pm 0.023$ & $0.496 \pm 0.022$ & $0.497 \pm 0.022$ & $0.495 \pm 0.022$ \\
\hline$\geq 140$ & 2109 & $0.485 \pm 0.023$ & $0.461 \pm 0.023$ & $0.501 \pm 0.022$ & $0.501 \pm 0.022$ & $0.500 \pm 0.022$ \\
\hline$\geq 168$ & 2046 & $0.494 \pm 0.023$ & $0.473 \pm 0.023$ & $0.509 \pm 0.023$ & $0.509 \pm 0.022$ & $0.509 \pm 0.023$ \\
\hline$\geq 196$ & 1965 & $0.500 \pm 0.023$ & $0.488 \pm 0.024$ & $0.516 \pm 0.023$ & $0.515 \pm 0.023$ & $0.516 \pm 0.023$ \\
\hline$\geq 224$ & 1807 & $0.492 \pm 0.025$ & $0.485 \pm 0.025$ & $0.512 \pm 0.024$ & $0.512 \pm 0.024$ & $0.512 \pm 0.024$ \\
\hline$\geq 252$ & 1608 & $0.517 \pm 0.026$ & $0.535 \pm 0.025$ & $0.529 \pm 0.025$ & $0.533 \pm 0.025$ & $0.530 \pm 0.025$ \\
\hline$\geq 280$ & 1286 & $0.539 \pm 0.029$ & $0.543 \pm 0.029$ & $0.540 \pm 0.029$ & $0.546 \pm 0.029$ & $0.540 \pm 0.029$ \\
\hline$\geq 308$ & 964 & $0.524 \pm 0.038$ & $0.524 \pm 0.038$ & $0.524 \pm 0.038$ & $0.524 \pm 0.038$ & $0.524 \pm 0.038$ \\
\hline
\end{tabular}

${ }^{1}$ Actual milk yield; ${ }^{2}$ Prediction equations had lactation length (>180 days) only (KHAN, 1986).

${ }^{3}$ Prediction equations based on last record-day procedure; only typical lactations of $\geq 308$ days duration were used in calculations.

${ }^{4}$ Prediction equations based on last record-day procedure; only typical lactations of $\geq 56$ days duration were used in calculations.

${ }^{5}$ Prediction equations based on last record-day procedure but having daily milk yield also; only typical lactations of $\geq 56$ days duration were used in calculations.

Table 7

Data structure for Animal Model analysis of lactation milk yield and lactation length (Datenstruktur der Tiermodellanalyse für Milchertrag und Laktationsdauer)

\begin{tabular}{lr}
\hline Description & Number \\
\hline No. of records & 2235 \\
No. of animals & 1023 \\
No. of "Base" animals & 300 \\
No. of animals with records & 780 \\
No. of animals with unknown/pruned sire & 158 \\
No. of animals with unknown/pruned dam & 197 \\
No. of sires with progeny records & 78 \\
No. of dams with progeny records & 419 \\
No. of grand-sires with progeny records & 66 \\
No. of grand-dams with progeny records & 243 \\
\hline
\end{tabular}

Results from Animal Model analysis (Table 7) to estimate heritability and repeatability are presented in Table 8. Estimates were much lower as compared to PHS method. Actual milk yield was only $9.1 \%$ heritable. MYSRF and MYTP1 had heritabilities of 8.1 and $12.0 \%$ respectively (Table 8 ).

Table 8

Estimates of genetic and phenotypic variances and genetic parameters under Animal Model (Schätzwerte der genetischen und phänotypischen Varianz sowie der genetischen Parameter mittels Tiermodell)

\begin{tabular}{|c|c|c|c|c|c|}
\hline \multirow[b]{2}{*}{ Description } & \multirow[b]{2}{*}{ MYTOT $^{1}$} & \multicolumn{4}{|c|}{ Milk yield adjusted for lactation length } \\
\hline & & MYSRF $^{2}$ & MYTP1 $^{3}$ & MYTP2 $^{4}$ & MYTP3 $^{5}$ \\
\hline Additive genetic $\sigma^{2}$ & 47555.7 & 42470.8 & 43330.6 & 43945.8 & 42392.6 \\
\hline Second animal $\sigma^{2}$ & 201231.2 & 190481.2 & 137793.6 & 155356.7 & 157300.4 \\
\hline Error $\sigma^{2}$ & 276014.2 & 288792.3 & 178972.7 & 196577.5 & 197084.6 \\
\hline Phenotypic $\sigma^{2}$ & 524801.5 & 521744.4 & 360097.0 & 395879.5 & 396777.6 \\
\hline Heritability & $0.091 \pm 0.047$ & $0.081 \pm 0.041$ & $0.120 \pm 0.055$ & $0.111 \pm 0.052$ & $0.107 \pm 0.058$ \\
\hline Repeatability & $0.383 \pm 0.047$ & $0.365 \pm 0.043$ & $0.383 \pm 0.053$ & $0.392 \pm 0.050$ & $0.396 \pm 0.054$ \\
\hline
\end{tabular}

${ }^{1}$ Actual milk yield; ${ }^{2}$ Prediction equations had lactation length (>180 days) only (KHAN, 1986).

${ }^{3}$ Prediction equations based on last record-day procedure; only typical lactations of $\geq 308$ days duration were used in calculations.

${ }^{4}$ Prediction equations based on last record-day procedure; only typical lactations of $\geq 56$ days duration were used in calculations.

${ }^{5}$ Prediction equations based on last record-day procedure but having daily milk yield also; only typical lactations of $\geq 56$ days duration were used in calculations. 
Repeatability estimates were in the range of 36.5 to $38.3 \%$, with MYSRF having repeatability of $36.5 \%$ and the MYTOT and MYTP1 having estimate of $38.3 \%$. CADY et al. (1983) reported that for lactations of $>60$ days length, within herd heritability was $25.4 \%$ but reduced to $7.1 \%$ for records of 305-days duration. Repeatability of the milk yield (22.9 to $26.5 \%$ ) was higher for lactations of $>60$ days duration as compare to lactations of 305-days. METRY et al. (1994) reported that heritability of milk yield increased as the records of shorter duration were deleted, similar to the present study. NORMAN et al. (1985) used first and second lactation records of U.S dairy breeds and suggested extension of all lactation records (complete or incomplete) for evaluation of animals.

Results of the Animal Model suggested that milk yield was 10-12\% heritable with a repeatability value between $35-40 \%$. The conclusions of PHS analysis did not change regarding the extension of milk yield using last record-day milk yield or by simple linear regression procedure. The extended records had better genetic parameter estimates and although, information on the reasons of shorter lactations was very limited, lactation milk yields extended by last record-day procedure using especially the average daily milk yield for the known part of the lactation, improved adjustments and heritability and repeatability estimates.

The studies that have suggested the use of lactation length as the only trait for selection because when milk recording is difficult at field level (DAHLIN, 1998) are based on the completed lactations where lactation length was adjusted as a fixed effect to estimate genetic and environmental factors. The review of SYRSTAD (1993) for zebu cattle also concludes that either the shorter lactations should be used as such (unextended) or a selection index having lactation length and milk yield be used. Present study does not agree with both of the mentioned studies because methods of extending shorter lactations from last record-day information can more precisely estimate credit given to an incomplete or completed lactations especially when average daily milk yield is included among the predictors. Standard lactation milk yield could be more precisely predicted and the genetic parameter estimates improved. A detailed study has previously explored the issue of the development of a selection index (KHAN, 1997) to have appropriate weightage to both milk yield and lactation length (SYRSTAD, 1993; DAHLIN, 1998). It was concluded that although, genetic correlation between the two trait is high (0.70) and inclusion of lactation length in a selection index with milk yield could improve the selection response slightly (104 vs $103 \mathrm{~kg}$ ) absence of precise selection weights and complexity of multiple trait model did not justify the use of such a selection index for Nili-Ravi buffaloes. Test-day models are being developed for use in buffaloes like other species (HORSTICK and DISTL, 2002; AMIN, 2003; BÖMKES et al., 2004; HINRICHS et al., 2006) but data formats require drastic changes to incorporate these models for recording and selection of buffaloes, similar to those suggested (SWALVE, 1995) for cattle breeds.

Phenotypic trend in lactation milk yield was negative in the present study. Heritability estimates improved when lactations were adjusted to 308 days even if information on reasons for lactations to be shorter was not available / used. Data were limited for Animal Model analysis yet adjusted records had higher heritability and a similar repeatability estimates. Shorter lactations (completed or incomplete) should be projected to a standard such as 305-days by using last record-day yield and average 
daily milk yield information to have better additive genetic variation and improved heritability and repeatability estimates and consequently faster improvement.

AKRAM, M.:

\section{References}

Genetic and phenotypic aspects of diurnal variation in milk yield of buffaloes. M.Sc. Thesis., Dept.

AMIN, A.A.: Anim. Breed. Genet., Univ. Agric., Faisalabad (1997).

Test-day model of daily milk yield prediction across stages of lactation in Egyptian buffaloes. Arch. Tierz., Dummerstorf 46 (2003), 35-45

BÖMKES, D.; HAMANN, H.; DISTL, O.:

Schätzung genetischer Parameter für Testtagsergebnisse von Milchleistungsmerkmalen bei Bunten Deutschen Edelziegen. Arch. Tierz., Dummerstorf 47 (2004), 193-202

CADY, R.A.; SHAH, S.K.; SCHERMERHON, E.C.; MCDOWELL, R.E.:

Factors affecting performance of Nili-Ravi buffaloes in Pakistan. J. Dairy Sci. 66 (1983), 578-286

DAHLIN, A.:

Genetic studies on Sahiwal cattle in Pakistan. Ph.D. Thesis, Swedish Univ. Agric. Sci. Uppsala (1998)

HARVEY, W.R.:

User's Guide for LSMLMW and MIXMDL, Mixed Model Least-squares and Maximum Likelihood computer program. PC-2 version. The Ohio State University, Columbus, OH, USA (1990)

HINRICHS, D.; STAMER, E.; JUNGE, W.; KALM, E.:

Genetic analysis of several disease categories using test day threshold models in German Holstein cows. Arch. Tierz., Dummerstorf 49 (2006), 3-16

HORSTICK, A.; DISTL, O.:

Schätzung genetischer Parameter für Testtagsergebnisse der Milchleistung bei ostfriesischen Milchschafen mit Bayes-Methoden für longitudinale Daten. Arch. Tierz., Dummerstorf 45 (2002), 6168

KHAN, M.A.:

Genetic analysis of a purebred herd of Nili-Ravi buffalo. Ph.D. Thesis, Dept. Anim. Breed. Genet., Univ. Agric., Faisalabad, Pakistan (1986)

KHAN, M.A.; IQBAL, J.:

Recent developments in buffalo breeding research in Pakistan. Proc. $2^{\text {nd }}$ Asian Buffalo Association Cong. Manila, Philippines (1996), Oct. 9-12

KHAN, M.S.:

Adjustment of milk yield for lactation length in Nili-Ravi buffaloes. Pakistan J. Agric. Sci. 33 (1996), 77-81

KHAN, M.S.:

Response to selection for milk yield and lactation length in buffaloes. Aisan-Aust. J. Anim. Sci. 10 (1997), 570-576

KHAN, M.S.; HYDER, A.U.; BAJWA, I.R.; REHMAN, M.S.; HASSAN, F.:

Prediction of lactation yield from last-record day and average daily yield in Nili-Ravi buffaloes. Pakistan Vet. J. 25 (2005), 175-178

METRY, G.H.; MOURAD, K.A.; WILK, J.C.; MCDANIEL, B.T.:

Lactation curve of first lactation Egyptian buffalo. J. Dairy Sci. 77 (1994), 1306-1314

MEYER, K.:

User notes of DFREML. Version $3.0 \alpha$ (1997)

NORMAN, H.D.; DICKINSON, F.N.; WRIGHT, J.R.:

Merit of extending completed records of less than 305 days. J. Dairy Sci. 68 (1985), 2646-2654

PILLA, A.M.; MOIOLI, B. M.:

Genetic evaluation of buffaloes for milk yield using the Animal Model. Zoot. Nutr. Anim. 18 (1992)

207-218 (Anim. Breed. Abstr. 61 (1993), 4240)

SAS/STAT ${ }^{\circledR}:$

User's Guide, Version 6. SAS Inst., Inc., Cary, NC. USA (1990)

SWALVE, H.H.

Test day models in the analysis of dairy production data - a review. Arch. Tierz., Dummerstorf 38 (1995), 591-612

SYRSTAD, O:

Milk yield and lactation length in tropical cattle. World Anim. Rev. 74/75 (1993), 68-72 
VAN VLECK, L.D.; HENDERSON, C.R.:

Regression factors for extending part-lactation milk records. J. Dairy Sci. 44 (1961), 1085-1091 WOOD, P.D.P.:

Algebric model of the lactation curve in cattle. Nature (London) 216 (1967), 164-165

Received: 2005-11-05

Accepted: 2007-03-25

Authors' address

Dr. M. SAJJAD KHAN, FAIZ UL HASSAN, M. SAIF UR REHMAN,

ASAD ULLAH HYDER, IMRAN RAFIQUE BAJWA

Department of Animal Breeding and Genetics, University of Agriculture,

FAISALABAD 38040, PAKISTAN

E-Mail: drsajjad2@yahoo.com 